vegetation maps. At the present time vast quantities of air photographs of Europe, Africa and elsewhere must be accumulating, and it is to be hoped that they will become available to ecologists, who will then be in a position to study vegetation on a scale comparable to that of Davis.

The second paper, on the sand keys of Florida, is of particular interest because it adds a new set of vegetation maps to the series started by Millspaugh in 1907 and continued by Bowman in 1917. Changes in the vegetation of these keys over a period of thirty-seven years can therefore be studied. The Marquesas, like Jamaica, have few or no living corals, whereas living corals abound in the Tortugas. This is a peculiar feature of the Caribbean and one which greatly needs investigation. Davis concludes that marine currents are the main agents in the formation of these keys; but it is elear also that hurricanes have had a profound influence in the past upon their structure and also their vegetation. Two types of vegetation are recognized, the sea-strand and the mangrove swamp. The use of habitat is employed in the ecological nomenclature. This has been discouraged by most ecologists working in temperate climates, but tropical vegetation, and especially that of maritime regions, appears to have problems of its own. It may eventually prove desirable in such cases to employ a habitat nomenclature. I encountered a similar difficulty in Jamaica. The number of species recorded by Davis is not large; but this is typical of small islands of this type. The climates of the island groups vary sufficiently for the biological life-form spectra to show significant differences. The Schimperian view of 'physiological dryness' is adopted for the mangrove habitat; but the evidence available to-day scarcely supports such an interpretation.

The third paper covers the whole of Southern Florida, and all the various features are considered with a view to future regional utilization and planning. Aeroplanes, cars, special tractors and 'airboats' enabled the author to visit many areas that were previously almost inaccessible. Much of the region is, of course, covered by the famous Everglades. 'Glades' are grasslands flanked by forests, the 'ever' being added to signify that they remain green throughout the year. Much of the Everglades is dominated by the saw-grass, Mariscus jamaicensis, but there are also prairies, sloughs and 'hammocks'. These swamps originated as a result of regular seasonal flooding. The 'dismal' swamps with pine and eypress do not form part of the glades. The whole area can be regarded as a huge alkaline peat-bog, in many ways comparable to what the British Fens must have looked like in the past. Vast deposits of peat are here being formed under subtropical conditions. Unfortunately the natural water conditions have been upset and this is bringing about changes in the organic soils and the vegetation. The area is becoming drier and saw-grass is being replaced by bushes (= carr stage of Wicken Fen). The annual transpiration and evaporation from the saw-grass area is often more than the annual rainfall, and hence the water relations are closely bound up with those

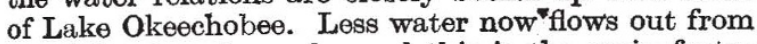
this lake than formerly, and this is the main factor responsible for the present changes. Piles of marine shells found inland indicate past ease of travel by innumerable waterways many of which have now silted up. There is evidently scope here for a combination of archæological and botanical research in a manner similar to that so successfully carried out by Godwin and his co-workers in Great Britain.

Ten physiographic regions are recognized for Southern Florida and at least three old shore lines. The sands left by these seas form the main shallow sand soils in which little or no profile has developed. Beneath the Everglades there is an impervious marl layer, and Davis believes that these swamps would never have arisen were it not for this marl layer which effectively impedes drainage. If this is true, then the Everglades are related neither to the present climate nor to existing physiography but to past geological changes. Although twenty soil types are recognized, peats and marls are the outstanding features of this region. The soils are generally shallow and they have been much" reduced by fires, which form an important determining factor of the environment. A detailed correlation is made between the different vegetation communities, individual species. and the soil types.

A study of the water relations showed that the ratio, time water-logged to time dry, is the most important factor. Because of the low relief a few inches change in elevation makes a profound differ. ence in the.drainage relations.

Nine main types of vegetation are recognized and fifteen types are represented on the vegetation map. There is a very high proportion of woody plants, and Davis concludes that a.t least one half of the area is economically unprofitable and best left in the wild state. The characteristic 'hammock' forests represent the climax vegetation in Southern Florida. These possess a great diversity of plants, many of the species being tropical. If the fire danger were controlled these forests would be larger, while even at present their arrangement provides an indication of the drainage relations. Davis also considers that the cypresses (Taxodium) will not invade an area where water is continually standing on the surface because the seedlings require atmospheric oxygen.

These three papers contain many more valuable observations, but sufficient has been said to indicate their scope and importance.

\section{BIOLOGY IN WAR-TIME CHINA*}

\author{
BY DR. PEI-SUNG TANG \\ Director of the Tsing Hua University Physiological
Laboratory
}

$T$ HIS article will be of the nature of a report on the movements of biological institutions during the War and the activities of biologists associated with those institutions. No attempt will be made to survey the entire field of biology in war-time China, or to evaluate the work at present being done by Chinese biologists.

During the decade immediately preceding the War, there were several centres of biological investigation in China from which came a steady output of research. There were, for example, the physiologists at the Peiping Union Medical College, gathered round Robert K. S. Limt, who virtually founded the science of physiology in China; the biochemists, whom $H$. Wu brought together in the same College; the Fan

* Condensed version.

$\dagger$ The Romanized names of the biologists mentioned in this article are those used by the authors in their publications. 
Memorial Institute of Biology, where H. H. Hu and C. Ping established their School of Systematic Biology; and the Biological Institutes of Academia Sinica and of the Peiping Academy. The extent to which the work of these Institutes has been affected by the War differs greatly in individual cases.

The group led by Robert Lim included such men as H. C. Chang, known for his work on acetylcholine, and T. P. Feng, a pupil of Prof. A. V. Hill, whose review of muscle-nerve physiology appeared in the Ergebnisse der Physiologie shortly before the outbreak of war. Around this group was built the Chinese Physiological Society, and to it goes the credit of publishing the Chinese Journal of Physiology, perhaps the Chinese journal best known abroad. When war broke out in 1937, Lim was away in Malaya; but he returned to China and offered his services to the Government. In the winter of 1937 , shortly before the fall of Nanking, he had but a handful of helpers. From that small start his Medical Relief Corps grew in three years to a sizeable army numbering thousands. This body rendered invaluable service to the fighting troops, not only in China but also in the Burma campaign, for which services Lim was decorated, by both the British and the United States Governments.

Lim is still with the Chinese Expeditionary Forces, serving in the capacity of medical supervisor, but he has now the added responsibility of establishing an Institute of Experimental Medicine for Academia Sinica. Of his former colleagues in Peiping, T. P. Feng has just arrived in Chungking and is temporarily attached to the Shanghai Medical College.

To the best of my knowledge, of the biochemists in H. Wu's department only C. Y. Chang, who is now attached to the Chung Cheng Medical College in Kiangsi, has as yet reached Free China. He was called to that College by Iping Chao, formerly of Tsing Hua University. With them is T. H. Chang, a nerve physiologist, formerly with the Biological Institute of the Science Society of China.

Of the original staff of the Fan Memorial Institute of Biology in Peiping, only its director, H. H. Hu, has reached the interior; this was shortly before the attack on Pearl Harbour. The work of the Institute is now carried out in part by the members of the Yunnan Institute of Economic Botany, established in the early part of the War as a result of Hu's farsightedness. The Institute continues the survey work started by the Fan Memorial Institute some years ago, paying particular attention to the economic possibilities of plants endemic in the south-western provinces. Also located in Yunnan is the former Botanic Garden of Lushan, directed by the fern specialist, J. C. Ching. Part of the Fan Memorial Institute has moved to Chung Cheng University, in Kiangsi, of which Hu was president for several years.

Shortly after the fall of Nanking, the Biological Institute of the Science Society of China moved from Shanghai to the interior. The director, T. H. Chien, a veteran botanist held in affection by all, suffered great hardship on the long journey from the coast to the interior; but, undaunted, succeeded in moving practically all the equipment and a library of that Institute to a town not far from Chungking, where with a group of faithful colleagues.he continues his work on systematic botany. Situated in the same town is the Institute of Zoology and Botany of Academia Sinica, which moved to the interior with its personnel and equipment almost intact during the early years of the War. H. W. Wu, C. C. Wang, C. C. Jao, Sicien Chen, C. C. Teng and others are carrying out research work on freshwater biology, entomology, parasitology, mycology and plant pathology.

Formerly there were four Institutes of Biological Studies in the Peiping Academy, namely the ZooIogical, Botanical, Physiological and Pharmacological Institutes. Of these the first three moved to Yunnan at the beginning of the War, and the last was left in Shanghai. On the death of Ting-heng Lou, the Zoological Institute was combined with the Physiological Institute, under the direction of Li-ping King. King himself is working on the pharmacology of Chinese herb medicine, while Tchang-si of the same department is conducting extensive surveys of the fishes of Yunnan from the point of view of their economic possibilities. Liou Tchenngo of the Botanical Institute has been making botanical surveys in the south-western parts of China. The director of the Pharmacological Institute, Tzan-Quo Chou, is still in Shanghai.

Also in Shanghai are two other well-known biologists who when last heard of were still engaged on their peace-time researches. One of these is C. Ping, the veteran zoologist who remained behind after the Biological Institute of the Science Society moved to the interior. The other is Tshou-su, who was provided with working facilities in his Institut de Biologie de Shanghai by the British Fund Committee.

C. Tsai has been "the moving spirit behind the Medical School of the National Central University, which was transferred to Chengtu shortly after the War began. He has gathered around him a group of young men, including $\mathrm{F}$. Y. Hsu and J. P. Chu, who are working mainly on the anti-hæmolytic action of lecithin and cholesterol. Tsai is now in the United States as one of six university professors invited by the State Department. With Tsai for a time were T. C. Tung and Mrs. Tung, who have now joined the national Tung Chi University in Szechuan and have been able to keep up their work on experimental embryology.

The National University of Chekiang moved to the interior shortly after the War began, first to Kiangsi, then to Kwangsi, and finally to Kweichow. Under the leadership of Sitsan Pai there has aricen one of the most active centres of biological research in wartime China. Apart from Pai, who published two articles on cytogenetics in the first issue of Science Record, the department has on its staff C. C. Tan, the geneticist, and T. L. Loo. Burg Tsai, formerly attached to the same department, is now director of the newly established Chinese Institute of Sericulture in the same province. This Institute was opened three years ago and is supported by the British Fund Committee.

The Institute of Psychology of Academia Sinica was moved to Kweilin during the first years of the War. It is situated in a picturesque town not far from the provincial capital, along with the Institutes of Physics and Geology of Academia Sinica. G. H. Wong, the director of the Institute, is continuing his work on physiological psychology, with tadpoles as experimental material. From the city of Kweilin comes news that Amos Kwangchin Penn has discovered in Kwangsi several species of plants which give fairly good yields of rubber and is exploring their industrial possibilities. Penn was formerly connected with the National Tsing Hua University, but 
joined the National Kwangsi University after the fall of Hong Kong.

The work of the Physiological Laboratory of the National Wuhan University is in charge of Zangying Gaw, who works on cellular physiology, especially on the growth and metabolism of nitrogen-fixing bacteria. His work is partly supported by the Rockefeller Foundation.

At the National Southwest Assoeiated University are to be found under one roof the National Tsing Hua University, the National University of Peking and the National Nankai University. Here four groups of biologists are engaged in research. In the Department of Biology of the University proper, Sesan Chen, the ecologist, works on the behaviour of ants. In the same Department, under the leadership of C. Y. Chang, head of the Department of Biology of the National University of Peking, a group of young men are working on physiological aspects of plant morphology. Mrs. Chang (née C. L. Tsui) is head of the Department of Biology at the nearby National Yunnan University, and continues her embryological studies with a group of young colleagues.

In the same University are the three divisions of the Tsing Hua University Institute of Agricultural Research. The Entomological Division is in charge of C. L. Liu. With him is C. J. Lu, formerly attached to the group of entomologists at Soochow University. Liu is particularly interested in the biological control of insect pests. A wealth of information on this subject has been accumulated and now awaits publication.

The second division of the Tsing Hua University Institute of Agriculture Research is the Division of Plant Pathology headed by the veteran mycologist F. L. Tai. With the able assistance of T. F. Yu, they are accumulating information on the fungi of Yunnan and on the breeding of disease-resistant varieties of crop plants.

My own department, the Physiological Laboratory of Tsing Hua University, is the third division of the Agricultural Institute. It was established in 1938 after the University had moved to Yunnan. It has been my good fortune to invite to my laboratory such able men as H. C. Ying, C. H. Lou, T. Shen and S. C. Pan. Although Ying is now officially on the staff of Peking University, Pan on the staff of the Department of Engineering and Shen in the Department of Biology, common interests and the convenience of sharing our limited resources have kept us together ever since their arrival at the laboratory. The Tsing Hua University Physiological Laboratory is dedicated to research in the broad field of general physiology, attacking certain fundamental physiological processes with the aid of physical and ehemical procedures. Ying is engiged in plant hormone research and biochemical aspects of plant physiology. Lou is studying action potentials in plants and is interested in the problems of electro-physiology in general. Pan has been concerned, with the industrial applications of micro-organisms, especially with the problem of alcoholic, acetic and lactic fermentations, while Shen's main interest is in the field of nutrition. My own work on cellular respiration still continues. For their work on the physiology of the silk-worm, several members of the laboratory were awarded the Ting Prize of Academia Sinica last year.

Interest in nutrition research is at present sweeping the country like wildfire, and a large number of biologists and biochemists are now engaged on work in this field. The reason for their enthusiasm is twofold. In the first place, existing conditions in the country necessitate the most economical management of our food resources; secondly, nutritional data are much needed for planning agricultural production in the general scheme of post-war reconstruction. Early in 1941 the National Bureau of Public Health called a conference on nutrition in Chungking which has resulted in the mapping out of a comprehensive programme of co-ordinated research in nutrition and food planning for the nation, to be carried out in collaboration with existing centres of investigation. Another result of the conference has been the formation of the Chinese Society of Nutrition, an organization devoted to the advancement of nutrition research in China.

Among the various institutions in which nutrition research is being carried out at the present time may be mentioned the Central University Medical College Department of Biochemistry, where Libin T. Cheng and his colleagues are determining the nutritive values of Chinese foods. At the National Szechuan University C. Y. Chen is doing similar work on certain food products commonly found on the market, such as soya bean flour and preserved eggs. Chen's work is published in his own journal, the Nutrition Bulletin, which came into being while he was at the National Peiping Agricultural College. At that time T. Y. Lo was his associate, but at present Lo is conducting a laboratory of his own at the National Chekiang University.

An Army Nutrition Institute has recently been set up at the Army Medical College in Kweichow, with H. Wan"as director. The work of the Institute, as its title indicates, is chiefly concerned with nutrition problems in the Chinese Army. A number of publications havo already come from that Institute in the form of bulletins and pamphlets, mainly for the benefit of army officers. At about the same time a nutrition laboratory was set up by the National Bureau of Public Health under C. F. Wang. The Institute is chiefly interested in Chinese diets and ehildren's nutrition. As mentioned above, an important part of the work on nutrition at the Tsing Hua University Physiological Laboratory is directed by T. Shen, who has made extensive surveys on nutrition conditions in the Chinese Army and the diets of college students.

An outstanding event in war-time biology in China has been the arrival of Dr. Joseph Needham, of the Cambridge Biochemical Laboratory. Through his extensive visits to many of the centres of biological research he has brought new information and fresh ideas to Chinese workers. He has also helped materially in obtaining chemicals and apparatus, as well as microfilmed literature, through the British Council's Cultural Scientifie Office in Chungking. To Dr. Needham and to Dr. John K. Fairbank, of the Office of the Cultural Attaché of the United States Embassy, biological workers in China are indebted for generous assistance.

Almost all the biological journals which were in circulation before the War have temporarily suspended publication because of insufficient facilities and economic pressure. The exceptions are Sinensia and the Chinese Journal of Experimental Biology, which are making a heroic struggle to appear, albeit irregularly. This accounts for the failure of other journals to reach our friends and libraries abroad. In place of these suspended journals, certain publications in foreign languages (mostly in English) have been brought out as a temporary measure. 
These include the Science Record of Academia Sinica, which has a section on biology. In addition, there are the Proceedings of the Chengtu Branch of the Chinese Physiological Society and the Biochemical Bulletin of the Tsing Hua University Physiological Laboratory.

The impression ereated by this article will perhaps be that practical aspects of biological research predominate in present-day China. This is true to a large extent; but there are still a number of centres where a major part of the work is on academic aspects of biology. This is especially true of the Institute of Psychology of Academia Sinica, and to a certain extent of the Tsing Hua University Physiological Laboratory. The trend towards research of practical value is in fact unavoidable. In the first place the need of the country at the present is certainly on the practical side, and in the second place it is extremely difficult to carry out academic research of real importance under present conditions. Added to these reasons is the desire of every biologist to make himself useful to the country in its war effort. It is therefore not surprising to find biochemists, for example, putting their energy into such problems as army nutrition, the industrial possibilities of certain rubber-producing plants, vegetable oils and fermentation; while most of the. systematic biologists have either turned their attention to agrieultural problems or undertaken biological surveys of hitherto unexplored country.

\section{OBITUARIES}

\section{Mr. Emil Hatschek}

Emm HatscheK, who died in London on June 4, at the age of seventy-five, carried out pioneer work in many branches of colloid science and did much to direct attention in England to this subject. In spite of the stimulus supplied by the classical researches of Thomas Graham, little was being done in this country on colloids when, in 1911, Hatschek started a systematic course of lectures on colloidal chemistry at the Sir John Cass Institute. This was, I believe, the first regular course on the subject to be given in England, and it continued until 1935, when Hatschek reached the age limit for retirement. From about 1910 until 1932 Hatschek was producing original papers, all marked by elegance and strong individuality, which appeared in various periodicals, including the Proceedings of the Royal Society, the Transactions of the Fraraday Society, Chemistry and Industry, the Biochemical Journal and the Transactions of the Institute of Mining and Metallurgy, apart from the twenty-six or so that appeared in the Kolloid-Zeitschrift. These names do something to indicate the width of interest of his work. His services to colloid science were acknowledged when he was made the guest of honour at the Colloid Symposium at Ottawa in 1932, a distinction much appreciated by him. His contribution at Ottawa was a paper on "The Study of Gels by Physical Methods", a subject to which he had devoted much attention.

Hatschek was a Hungarian by birth, but his family migrated to Vienna when he was a child, and it was in that city that he studied at the famous Polytechnicum. Engineering, however, was his subject in those days, and it was as an engineer that he came to Fngland in 1888, at the age of twenty. He became a naturalized British subject in 1900 . He concerned himself professionally with matters of chemical engineering, especially filtration, in both England and America : problems that he met in this work first dirècted his attention to colloid science. About 1910 he retired from active professional work, although he still acted as consultant to certain undertakings, and, possessing private means, devoted most of his time to original experiment.

Hatschek's fancy took him into unusual fields, and in each he found matters of interest and importance. Two curious contributions of his were, one, on the changes in form of spherical segments of elastic gelatine, which on drying formed a gastrula reminiscent of the behaviour of living embryos, and, the other, on the growth of crystals in gels, which had a marked bearing on the growth of minerals. In particular, he showed that with gold the various forms that can be observed when crystals are formed in silica gel closely resemble the natural appearance of gold in quartz. His work on periodic precipitation bore on the banding observed in some natural minerals. He carried out many other elegant and unusual researches, but his greatest body of connected work was on various aspects of viscosity, especially on the anomalous viscosity of many classes of colloids. For this work his wide chemical knowledge, his clear-cut physical conceptions and his good general mathematical powers fitted him admirably. His co-axial cylinder viscometer for investigating the properties of colloidal solutions has been widely used.

In $19: 3$ Hatschek published his "Introduetion to the Physics and Chemistry of Colloids", which went into five editions. His "Laboratory Manual of Colloid Chemistry" also achieved wide popularity. In 1928 he produced his "Viscosity of Liquids", a standard work which was at once translated into German. $\mathrm{He}$ edited the "Foundations of Colloid Chemistry", a collection of classical papers, and wrote the articles on "Colloids" and "Viscosity" in the last edition of the "Encyclopaedia Britannica".

Hatschek was a man of very wide learning, with a fund of precise information on most matters. $\mathrm{He}_{\Theta}$ had an excellent knowledge of botany, especially of field botany; he was well versed in the history and theory of music, and was a good pianist ; in philology and general history he could hold his own in most companies; and be had a wide knowledge of the literature of England, France and Germany. He was a familiar figure at the Royal Institution and at the Faraday Society, in the government of which he played a prominent part for many years. In 1930 he became a member of the Savage Club, and was there almost daily to his death, acting in an oracular. capacity. He never married and, in fact, all his attachments were intellectual rather than emotional. A powerful and original personality, his passing leaves a gap in British science.

E. N. da C. Andrade.

\section{Dr. Burgess Barnett, M.B.E.}

Dr. BuRgess BARNETT, superintendent of the Rangoon Zoological Gardens since 1938, died on April 9 at Dooars, Bengal, at the age of fifty-six. $\mathrm{He}$ is perhaps.best known for his work on the use of snake venom in the treatment of hæmorrhage and epilepsy, mainly carried out while holding the appointment of curator of reptiles of the Zoological Society of London during 1932-37.

He was the son of the late H. F. Barnett of Bescot 